Vol.61: e18150711, 2018

http://dx.doi.org/10.1590/1678-4324-2018150711

ISSN 1678-4324 Online Edition
BRAZILIAN ARCHIVES OF

BIOLOGY AND TECHNOLOGY

AN INTERNATIONAL JOURNAL

\title{
Carbon Dioxide Biofixation and Production of Spirulina sp. LEB 18 Biomass with Different Concentrations of $\mathrm{NaNO}_{3}$ and $\mathrm{NaCl}$
}

\author{
Luiza Moraes ${ }^{1}$, Gabriel Martins da Rosa ${ }^{1}$, Michele da Rosa Andrade Zimmermann de \\ Souza ${ }^{1}$, Jorge Alberto Vieira Costa ${ }^{1 *}$ \\ ${ }^{I}$ Universidade Federal do Rio Grande - Escola de Químca e Alimentos, Laboratório de Engenharia Bioquímica, \\ Rio Grande, Rio Grande do Sul, Brasil
}

\begin{abstract}
Microalgae are efficient at using solar energy to turn $\mathrm{CO}_{2}$ and nutrients into biomass containing lipids, proteins, carbohydrates and other compounds that may be used to produce bioproducts for human and animal consumption and pharmaceutical use. The aim of this study was to assess the effect of the $\mathrm{NaNO}_{3}$ and $\mathrm{NaCl}$ concentration on the growth kinetics, the biomass composition and the ability to biofix $\mathrm{CO}_{2}$ using the microalga Spirulina sp. LEB 18 . The assays were carried out according to a $2^{2}$ central composite design (CCD) with different concentrations of $\mathrm{NaNO}_{3}\left(1.25,1.88\right.$ and $\left.2.50 \mathrm{~g} \mathrm{~L}^{-1}\right)$ and $\mathrm{NaCl}\left(1.00,15.0\right.$ and $\left.30.0 \mathrm{~g} \mathrm{L^{-1 }}\right)$. The assays were carried out in $2 \mathrm{~L}$ vertical tubular photobioreactors at $30^{\circ} \mathrm{C}, 12 \mathrm{~h}$ light/dark and an injection of $12.0 \% \mathrm{v} / \mathrm{v}$ of $\mathrm{CO}_{2}$ at $0.3 \mathrm{vvm}$. The best growing results $\left(X_{\max }=1.60 \mathrm{~g} \mathrm{~L}^{-1}, P_{\max }=0.109 \mathrm{~g} \mathrm{~L}^{-1} \mathrm{~d}^{-1}, \mu_{\max }=0.208 \mathrm{~d}^{-1}\right)$ and $\mathrm{CO}_{2}$ biofixation rate $\left(197.4 \mathrm{mg} \mathrm{L}^{-1} \mathrm{~d}^{-1}\right)$ were observed in the assay with $1.25 \mathrm{~g} \mathrm{~L}^{-1} \mathrm{NaNO}_{3}$ and $1.00 \mathrm{~g} \mathrm{~L}^{-1} \mathrm{NaCl}$. Increasing the $\mathrm{NaCl}$ concentration produced biomass with a higher carbohydrate content, while increasing the $\mathrm{NaNO}_{3}$ concentration reduced the protein concentration. According to the results, in addition to using Spirulina as a source of protein, it can also be used as a source of carbohydrates and to biologically remove $\mathrm{CO}_{2}$ from the atmosphere.
\end{abstract}

Keywords: $\mathrm{CO}_{2}$; fixation; growth kinetics; microalgae; nutrients.

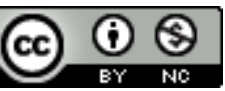

\footnotetext{
*Author for correspondence: jorgealbertovc@terra.com.br
} 


\section{INTRODUCTION}

In light of the growing concern about global warming and the sustainable management of resources, microalgae biotechnology is a promising alternative for reducing excess $\mathrm{CO}_{2}$ emissions and for treating wastewater because it can produce biomass, which has several uses (Hende et al. 2012).

Microalgal biomass can be a source of biocompounds, including lipids, proteins, carbohydrates, vitamins and pigments (Spolaore et al. 2006). These compounds can be processed into products with high added value, such as biopolymers, pharmaceuticals, cosmetics, human food and animal feed (Ho et al. 2011). Microalgae have many favorable characteristics: they present high biomass productivity, are tolerant to seasonal variations and have a high photosynthetic efficiency to fix $\mathrm{CO}_{2}$ and accumulate quantities of compounds, such as lipids and carbohydrates (Subhadra and Edwards, 2010).

The growth kinetics and biochemical composition of microalgae can be influenced by several factors: temperature, $\mathrm{pH}$, nutrient concentration of the medium, salinity, illuminance and growth phase. The definition of these parameters, whether qualitative or quantitative, can significantly change the biomass composition, inhibiting or stimulating the synthesis of biomolecules (Hu, 2004). Exposing the cultivations to conditions of stress, such as limited phosphorus and nitrogen (Mutlu et al. 2011), illuminance (Ho et al. 2012) and high salinity (Rao et al. 2007), may trigger the accumulation of biocompounds reserve.

Spirulina is a filamentous and alkaliphilic cyanobacterium. Its biomass is exceptional because it contains between 60 and $70 \%\left(\mathrm{w} \mathrm{w}^{-1}\right.$ ) proteins, pigments (such as chlorophyll and

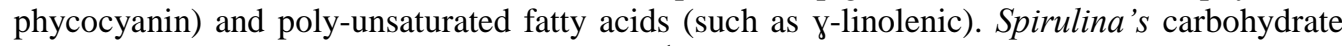
concentration can vary from 12 to $20 \%\left(\mathrm{w} \mathrm{w}^{-1}\right)$ and the lipid concentration from 6 to $13 \%$ (w $\mathrm{w}^{-1}$ ) (Cohen, 1997). Given these low values of reserve compounds, changes in the concentration of nutrients in the culture medium can increase the content of lipids and carbohydrates.

The carbon source that is required for Spirulina cultivation represents $60.0 \%$ of the costs with nutrient (Alava et al. 1997). The $\mathrm{CO}_{2}$ concentration of $10-15 \%$ is the average value found in the combustion gases of power plants (Lee et al. 2002). The use of carbon source alternative present in the combustion gases can minimize the problems that are caused by the emission of this greenhouse gas and reduce costs with this nutrient (Hughes and Benemann, 1997) for cultivation.

Therefore, the aim of this study was to investigate the effect of the $\mathrm{NaNO}_{3}$ and $\mathrm{NaCl}$ concentration on the growth kinetics, biomass composition and ability of Spirulina sp. LEB 18 to biofix $\mathrm{CO}_{2}$.

\section{MATERIALS AND METHODS}

\section{Microorganism and cultivation medium}

The microalga used was Spirulina sp. LEB 18 (Morais et al. 2008), which was maintained in Zarrouk medium (Zarrouk, 1966). This strain belongs to the Cultures Collection of the Laboratory of Biochemical Engineering, Federal University of Rio Grande (FURG).

\section{Adaptation of the inoculum}

The inoculum was prepared from an initial volume of $3.0 \mathrm{~L}$ and biomass concentration of $1.0 \mathrm{~g}$ $\mathrm{L}^{-1}$. This inoculum was filtered in a sterile environment. The cells that were collected in the filter paper were washed with sterile distilled water to remove the salts from the Zarrouk medium. The washed cells were recovered in $1.0 \mathrm{~L}$ of modified Zarrouk medium. The modification of the culture medium involved a reduction of $50 \% \mathrm{NaNO}_{3}$ (adaption to the lowest point of the experimental design) in the absence of $\mathrm{NaHCO}_{3}$ (original carbon source of Zarrouk medium). Then, this inoculum was maintained, with carbon dioxide $\left(\mathrm{CO}_{2}\right)$ as the new carbon source, in the concentration of $5.0 \% \mathrm{v} / \mathrm{v}$, flow rate of $0.3 \mathrm{vvm}$ (volume of gaseous mixture per volume of medium per min) for $15 \mathrm{~min}$, every $2 \mathrm{~h}$, in the light period. The $\mathrm{CO}_{2}$ specific flow rate was of $1.35 \mathrm{LCO} 2_{\mathrm{L}} \mathrm{Ldium}^{-1} \mathrm{~d}^{-1}\left(\mathrm{R}_{\mathrm{CO} 2 \mathrm{fed}}=1.35 \mathrm{~d}^{-1}\right)$. 


\section{Cultivation conditions}

The assays were carried out according to a $2^{2}$ central composite design (CCD) (4 assays +2 central points) (Table 1). The independent variables that were assessed in the culture medium were the concentrations of $\mathrm{NaNO}_{3}$ and $\mathrm{NaCl}$.

Table 1. $2^{2}$ CCD matrix with coded and actual levels of the variables

\begin{tabular}{lllll}
\hline Assay & $\mathbf{X}_{\mathbf{1}}(\mathbf{N a N O})$ & $\left.\mathbf{X}_{\mathbf{2}} \mathbf{( N a C l}\right)$ & $\mathbf{N a N O}_{\mathbf{3}}\left(\mathbf{g ~ L}^{-\mathbf{1}}\right)$ & $\mathbf{N a C l}_{\mathbf{~}}\left(\mathbf{g ~ L}^{-\mathbf{1}}\right)$ \\
\hline 1 & -1 & -1 & 1.25 & 1.0 \\
2 & +1 & -1 & 2.50 & 1.0 \\
3 & -1 & +1 & 1.25 & 30 \\
4 & +1 & +1 & 2.50 & 30 \\
5 & 0 & 0 & 1.88 & 15 \\
6 & 0 & 0 & 1.88 & 15 \\
\hline
\end{tabular}

The experiments were carried out in fed-batch mode with $\mathrm{CO}_{2}$ in $2 \mathrm{~L}$ vertical tubular photobioreactors with a working volume of $1.5 \mathrm{~L}$ at $30{ }^{\circ} \mathrm{C}, 12 \mathrm{~h}$ light/dark photoperiod, and $41.6 \mu$ mol $_{\text {photons }} \mathrm{m}^{-2} \mathrm{~s}^{-1}$ (Morais and Costa, 2007) for $14 \mathrm{~d}$. The stirring of the cultivations was promoted by the continuous injection of compressed air at $0.3 \mathrm{vvm}$, and during the light phase, the gas mixture was enriched with $12.0 \% \mathrm{v} / \mathrm{v}$ of $\mathrm{CO}_{2}$ for $15 \mathrm{~min}$ (Morais and Costa, 2007) every $2 \mathrm{~h}\left(\mathrm{R}_{\mathrm{CO} 2 \mathrm{fed}}=3.24 \mathrm{~d}^{-1}\right)$. In these conditions, but with no $\mathrm{CO}_{2}$ addition and with standard Zarrouk medium, a control assay was carried out. The daily variation in volume due to evaporation was corrected with the addition of sterile distilled water until the working volume of the photobioreactor was restored.

\section{Analytical determinations}

Samples were collected daily to monitor the biomass concentration. The biomass concentration (BC) was determined spectrophotometry using a standard curve of Spirulina sp. LEB 18 (Absorbance $=1.2515 * \mathrm{BC}+0.0478$, with $\mathrm{R}^{2}=0.9934$, and estimated error of $\left.3.38 \%\right)$. This curve was obtained by measuring the optical density of the Spirulina inoculum in a spectrophotometer at $670 \mathrm{~nm}$, by relating the optical density and dry weight biomass, as performed by Costa et al. (2002). At the end of the experiments, the biomass was centrifuged at $18,000 \mathrm{~g}$ for $20 \mathrm{~min}$ at $25^{\circ} \mathrm{C}$, resuspended three times in distilled water and then centrifuged again under the same conditions to remove salts from the medium. Subsequently, the biomass was dried at $40{ }^{\circ} \mathrm{C}$ for $24 \mathrm{~h}$ and stored at $-20{ }^{\circ} \mathrm{C}$ until its characterization.

The concentrations of carbon $(\mathrm{C})$ and nitrogen $(\mathrm{N})$ in the biomass were determined in an elemental analyzer (Perkin Elmer 2400, USA) using acetanilide as the standard. The protein concentration was calculated from the concentration of elemental nitrogen using 5.22 as the conversion factor, which is specific for cyanobacteria (Lourenço et al. 2004). The lipid concentration was determined using the Folch method (Folch et al. 1957). The concentration of carbohydrates in the biomass was determined by the adapted 3.5-DNS method (Miller, 1959) with the prior acid hydrolysis of polysaccharides.

\section{Assessment of the growth parameters}

The maximum biomass concentration $\left(\mathrm{X}_{\max }, \mathrm{g} \mathrm{L}^{-1}\right)$ of the Spirulina cultivations was obtained for each assay, and the kinetic parameters were calculated. The biomass productivity $\left(\mathrm{P}_{\mathrm{x}}, \mathrm{g} \mathrm{L}^{-1}\right.$ $\left.\mathrm{d}^{-1}\right)$ was calculated according to Equation 1, where $\mathrm{X}_{\mathrm{t}}\left(\mathrm{g} \mathrm{L}^{-1}\right)$ is the biomass concentration at time $\mathrm{t}(\mathrm{d})$, and $\mathrm{X}_{0}\left(\mathrm{~g} \mathrm{~L}^{-1}\right)$ is the biomass concentration at time $\mathrm{t}_{0}(\mathrm{~d})$. The maximum specific growth rate $\left(\mu_{\max }, \mathrm{d}^{-1}\right)$ was obtained from the exponential regression of the logarithmic phase of the microalgal growth.

$$
P_{x}=\frac{X_{t}-X_{0}}{t-t_{0}}
$$

\section{$\mathrm{CO}_{2}$ biofixation rate $\left(\mathrm{R}_{\mathrm{CO} 2}\right)$}

The $\mathrm{CO}_{2}$ biofixation rate $\left(\mathrm{R}_{\mathrm{CO} 2}, \mathrm{mg} \mathrm{L}^{-1} \mathrm{~d}^{-1}\right)$ was calculated according to Toledo-Cervantes et al. (2013), as shown in Equation 2. In this Equation $\mathrm{P}_{\max }\left(\mathrm{mg} \mathrm{L}^{-1} \mathrm{~d}^{-1}\right)$ was the maximum 
productivity for each assay, $\mathrm{x}_{\mathrm{cbm}}\left(\mathrm{mg}_{\text {carbon }} \mathrm{mg}_{\text {biomass }}{ }^{-1}\right)$ was the mass fraction of carbon as determined using an elemental analysis of biomass, and $\mathrm{M}_{\mathrm{CO} 2}$ and $\mathrm{M}_{\mathrm{C}}$ were the molar masses of carbon dioxide and carbon, respectively.

$\mathrm{R}_{\mathrm{CO}_{2}}=\mathrm{P}_{\max } * \mathrm{x}_{\mathrm{cbm}} * \frac{\mathrm{M}_{\mathrm{CO}_{2}}}{\mathrm{M}_{\mathrm{C}}}$

\section{Statistical Analysis}

The responses that were obtained in the experiments were evaluated by experimental design methodology use Statistica 6.0 software (StatSoft Inc., USA). The standard error was calculated based on the replications of the central points (pure error) (Teófilo and Ferreira, 2006) with a $95.0 \%$ confidence level.

\section{RESULTS AND DISCUSSION}

The profiles of the biomass concentration and biomass productivity of Spirulina sp. LEB 18 are shown in Figure 1. The microalga did not present a lag phase of growth due to the preadaptation of the inoculum, and the exponential phase was defined between the third and sixth days (Fig 1A), with coefficients of determination $\left(\mathrm{R}^{2}\right)$ greater than 0.99 for all assays.

The biomass concentration was similar for the seven assays during the 4 and $5 \mathrm{~d}$ of cultivation, even in those with the lowest $\mathrm{NaNO}_{3}$ concentrations $\left(1.25 \mathrm{~g} \mathrm{~L}^{-1}\right)$ and highest $\mathrm{NaCl}$ concentrations $\left(30 \mathrm{~g} \mathrm{~L}^{-1}\right)$. The highest profile of biomass concentrations (Fig 1A) and biomass productivity (Fig 1B) were observed in the assay using $1.25 \mathrm{~g} \mathrm{~L}^{-1} \mathrm{NaNO}_{3}$ and $1.0 \mathrm{~g} \mathrm{~L}^{-1} \mathrm{NaCl}$ and were observed lower profiles of these parameters in the control assay.

(a)

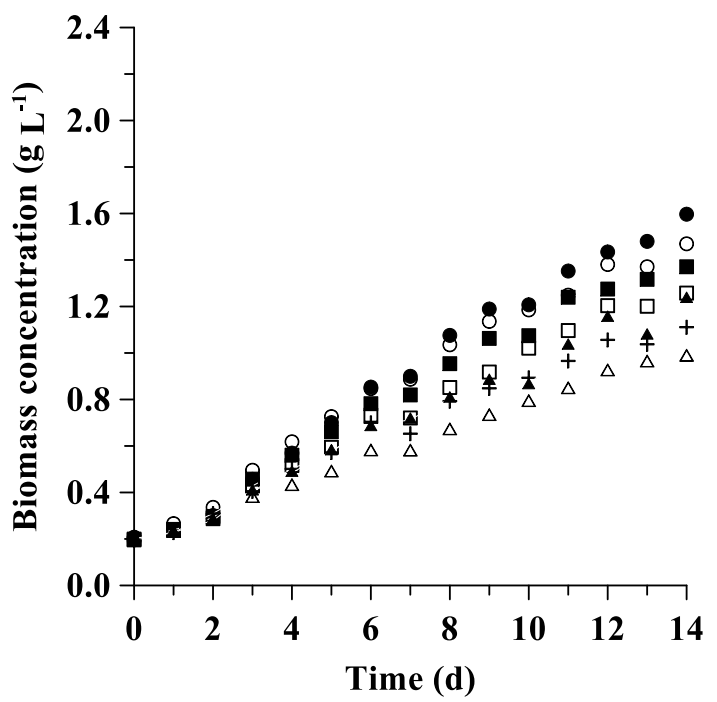

(b)

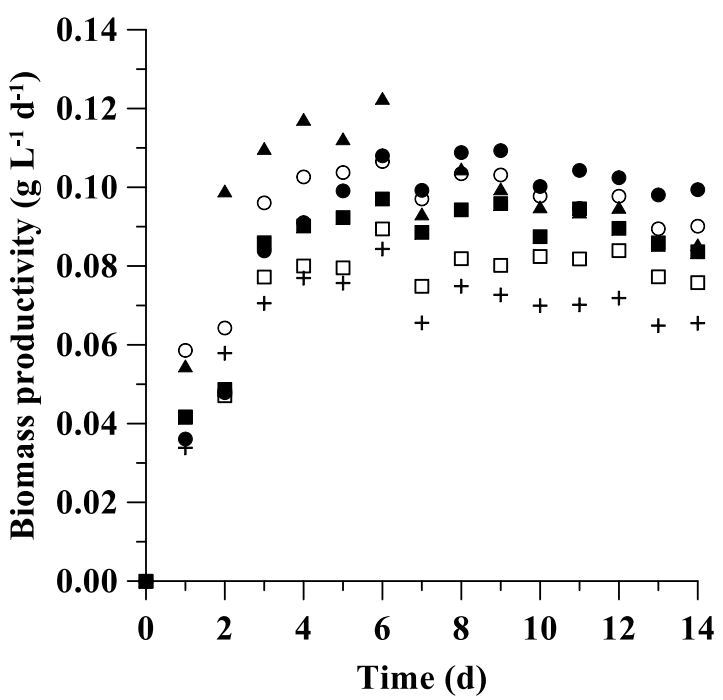

Figure 1. Profiles of biomass concentration (a) and biomass productivity (b) as a function of time for assays $1(\bullet), 2$ $(\circ), 3(\mathbf{\square}), 4(\square), 5(+), 6(\mathbf{\Delta})$ and control $(\Delta)$ as obtained with Spirulina sp. LEB 18 cultivation

Regarding the growth kinetics, the $\mathrm{NaNO}_{3}$ and $\mathrm{NaCl}$ concentrations in the culture medium and the interaction between the variables had no significant effect $(p>0.05)$ on the maximum biomass concentration, maximum biomass productivity or maximum specific growth (Table 2). Spirulina cultivations normally use Zarrouk medium, which contains $2.5 \mathrm{~g} \mathrm{~L}^{-1} \mathrm{NaNO}_{3}, 1.0 \mathrm{~g} \mathrm{~L}^{-1}$ $\mathrm{NaCl}$ and $16.8 \mathrm{~g} \mathrm{~L}^{-1} \mathrm{NaHCO}_{3}$. This study confirmed Spirulina tolerance to the changes in the concentrations of nutrients in the culture medium because the biomass productivity was maintained and was able to use $\mathrm{CO}_{2}$ as the carbon source, presenting better results than the control assay with Zarrouk medium. 
The growth that was observed in the cultivations with the highest tested $\mathrm{NaCl}$ concentrations tested (15.0 and $30.0 \mathrm{~g} \mathrm{~L}^{-1}$ ) corroborates the fact that Spirulina tolerates higher osmotic pressures compared to the concentration that Zarrouk medium usually provides, which is $1.0 \mathrm{~g}$ $\mathrm{L}^{-1}$ salt. Many cyanobacteria are considerably tolerant to saline stress because they have various physiological mechanisms, including the accumulation of inorganic or organic osmoregulators (Reed et al. 1986; Mackay et al. 1984) and the active extrusion of intracellular sodium (Gabbay-Azaria et al. 1992; Peschek et al. 1994).

Table 2. Real levels of the variables and maximum biomass concentration $\left(\mathrm{X}_{\max }\right)$, maximum biomass productivity $\left(\mathrm{P}_{\max }\right)$ and maximum specific growth rate $\left(\mu_{\max }\right)$ of Spirulina sp. LEB 18 cultivation

\begin{tabular}{llllll}
\hline \multirow{2}{*}{ sssay } & $\begin{array}{l}\mathbf{N a N O}_{\mathbf{3}} \\
\left(\mathbf{g ~ L}^{-\mathbf{}}\right)\end{array}$ & $\begin{array}{l}\mathbf{N a C l} \\
\left(\mathbf{g ~ L}^{-\mathbf{1}}\right)\end{array}$ & $\begin{array}{l}\mathbf{X}_{\max } \\
\left(\mathbf{g ~ L}^{-\mathbf{1}}\right)\end{array}$ & $\begin{array}{l}\mathbf{P}_{\max } \\
\left(\mathbf{g ~ L}^{-\mathbf{1}} \mathbf{d}^{-\mathbf{1}}\right)\end{array}$ & $\begin{array}{l}\boldsymbol{\mu}_{\max } \\
\left(\mathbf{d}^{-\mathbf{1}}\right)\end{array}$ \\
\hline 1 & 1.25 & 1.0 & 1.60 & 0.109 & 0.208 \\
2 & 2.50 & 1.0 & 1.47 & 0.107 & 0.177 \\
3 & 1.25 & 30 & 1.37 & 0.097 & 0.177 \\
4 & 2.50 & 30 & 1.26 & 0.089 & 0.175 \\
5 & 1.88 & 15 & 1.11 & 0.084 & 0.177 \\
6 & 1.88 & 15 & 1.23 & 0.080 & 0.174 \\
\hline Control* & 2.50 & 1.0 & 0.99 & 0.062 & 0.104 \\
\hline
\end{tabular}

*Control assay carried out with no $\mathrm{CO}_{2}$ addition

The highest values of biomass concentration, biomass productivity, and specific growth rate were observed in assay 1 , with $1.0 \mathrm{~g} \mathrm{~L}^{-1} \mathrm{NaCl}$ and $1.25 \mathrm{~g} \mathrm{~L}^{-1} \mathrm{NaNO}_{3}$ (Table 2). This result shows that the $50.0 \%$ reduction in the nitrogen source was not a limiting factor for the growth of the microalga. When there is a shortage of a nitrogen source, the microalga's metabolism can use chlorophyll and other pigments as an intracellular nitrogen source (Jiang et al. 2011). Colla et al. (2007) found that a 75.0\% reduction in the $\mathrm{NaNO}_{3}$ concentration of a Spirulina cultivation did not reduce the biomass productivity.

Our study corroborates this result, as the concentration of $\mathrm{NaNO}_{3}$ was reduced by $50.0 \%$ compared to the standard concentration of Zarrouk medium.

Increased of salinity normally harms cell growth due to the higher level of ionic and osmotic stress. This damage is due to changes in the ionic cellular proportions and to the selective permeability of the cell membrane to ions (Brand, 1984; Glass, 1983). This study found that 15.0 and $30.0 \mathrm{~g} \mathrm{~L}^{-1} \mathrm{NaCl}$ in the culture medium reduced the maximum biomass concentration by $30.6 \%$ and the biomass productivity by $26.6 \%$, taking into account the maximum and minimum values that were reached among the assays for both studied responses.

Some studies have shown that $30 \mathrm{~g} \mathrm{~L}^{-1} \mathrm{NaCl}$ in the medium may affect the activity of photosystem II and the energy transfer processes of the proteins in Spirulina's thylakoid membrane (Sudhir et al. 2005). Ravelonandro et al. (2011) cultivated Spirulina platensis in Zarrouk medium with 13.0 and $30.0 \mathrm{~g} \mathrm{~L}^{-1} \mathrm{NaCl}$ and found a reduction in the maximum biomass concentration (from 1.6 to $1.0 \mathrm{~g} \mathrm{~L}^{-1}$ ) and maximum biomass productivity (from 0.08 to $0.05 \mathrm{~g} \mathrm{~L}^{-1} \mathrm{~d}^{-1}$ ). The results that were obtained in this study (assay $3, \mathrm{X}_{\max }=1.37 \mathrm{~g} \mathrm{~L}^{-1}$ and $\mathrm{P}_{\max }=$ $0.097 \mathrm{~g} \mathrm{~L}^{-1} \mathrm{~d}^{-1}$ ) showed that the genus Spirulina can produce superior results, even when submitted to the same saline stress $\left(30.0 \mathrm{~g} \mathrm{~L}^{-1}\right)$ and a $50.0 \%$ reduction of the nitrogen source.

In the cultivation of Spirulina sp. LEB 18 and Scenedesmus obliquus LEB 22 in three photobioreactors in series and with the addition of $12 \% \mathrm{CO}_{2}$ was obtained the average biomass productivity among three reactors of 0.080 and $0.050 \mathrm{~g} \mathrm{~L}^{-1} \mathrm{~d}^{-1}$, respectively (Radmann et al. 2011). These results are lower than those in this study, demonstrating that the concentrations of $\mathrm{NaCl}$ and $\mathrm{NaNO}_{3}$ in the culture medium can be manipulated to not promote losses of biomass productivity. In the control assay employed were the same $\mathrm{NaNO}_{3}$ and $\mathrm{NaCl}$ concentrations of assay 2, however without the addition of $\mathrm{CO}_{2}$. In this context, it is believed that $\mathrm{CO}_{2}$ employment was better assimilated as carbon source and promoted greater growth. 
Table 3. Concentration of proteins, carbohydrates, lipids and elemental carbon in the biomass and $\mathrm{CO}_{2}$ biofixation rate $\left(\mathrm{R}_{\mathrm{CO} 2}\right)$ for Spirulina sp. LEB 18

\begin{tabular}{|c|c|c|c|c|c|}
\hline Assay & $\begin{array}{l}\text { Proteins } \\
\left(\% w_{w^{-1}}\right)\end{array}$ & $\begin{array}{l}\text { Carbohydrates } \\
\left(\% \mathbf{w ~ w}^{-1}\right)\end{array}$ & $\begin{array}{l}\text { Lipids } \\
\left(\% w^{-1}\right)\end{array}$ & $\begin{array}{l}\text { Carbon } \\
\left(\% w^{-1}\right)\end{array}$ & $\begin{array}{l}\operatorname{RcO2} \\
\left(\mathrm{mg} \mathrm{L}^{-1} \mathbf{d}^{-1}\right)\end{array}$ \\
\hline 1 & 62.4 & 11.3 & 10.3 & 49.2 & 197.4 \\
\hline 2 & 60.1 & 15.3 & 16.7 & 48.6 & 189.7 \\
\hline 3 & 60.3 & 16.7 & 9.2 & 49.5 & 176.2 \\
\hline 4 & 55.8 & 14.8 & 10.3 & 46.0 & 150.9 \\
\hline 5 & 55.6 & 20.8 & 15.9 & 48.3 & 149.5 \\
\hline 6 & 56.0 & 20.6 & 12.6 & 48.3 & 141.5 \\
\hline Control* & 58.3 & 15.4 & 12.8 & 48.6 & - \\
\hline
\end{tabular}

*Control assay carried out with no $\mathrm{CO}_{2}$ addition

Limiting the nitrogen source in the cultivation of microalgae encourages the metabolism of lipids and carbohydrates. The carbon that is present in the cells will be directed to the production of reserve compounds. Therefore, competition between the synthesis of lipids and carbohydrates will occur, given that the latter are the first reserve compounds to be synthesized, followed by lipids, which are stored when the period of nitrogen shortage is longer (Siaut et al. 2011).

Table 4 presents the estimate of the main effects $(\mathrm{L})$ of the concentration of $\mathrm{NaNO}_{3}\left(\mathrm{~g} \mathrm{~L}^{-1}\right)$, the concentration of $\mathrm{NaCl}\left(\mathrm{g} \mathrm{L}^{-1}\right)$ and the effect of the interaction between them on the concentration of proteins, carbohydrates and lipids found in the biomass of Spirulina and in the $\mathrm{CO}_{2}$ biofixation rate by Spirulina cultivation.

Table 4. Estimate of the main effects (L) and interaction between the variables for the concentrations of proteins, carbohydrates, lipids in the biomass and $\mathrm{CO}_{2}$ biofixation rate $\left(\mathrm{R}_{\mathrm{CO} 2}\right)$ for Spirulina sp. LEB 18

\begin{tabular}{lllllllll}
\hline \multirow{2}{*}{ Factor } & Proteins & \multicolumn{4}{l}{ Carbohydrates } & Lipids & \multicolumn{2}{l}{ R CO2 } \\
\cline { 2 - 10 } & Effect & $\mathbf{p}$ & Effect & $\mathbf{P}$ & Effect & $\mathbf{p}$ & Effect & $\mathbf{p}$ \\
\hline Mean & 58.4 & 0.001 & 14.5 & 0.002 & 12.5 & 0.050 & 167.7 & 0.009 \\
Curvature & - & - & 12.4 & 0.010 & - & - & - & - \\
$\mathrm{NaNO}_{3}(\mathrm{~L})$ & -3.39 & 0.048 & 1.04 & 0.090 & 3.77 & 0.360 & -16.4 & 0.211 \\
$\mathrm{NaCl}_{(\mathrm{L})}$ & -3.18 & 0.052 & 2.44 & 0.040 & -3.78 & 0.360 & -29.9 & 0.118 \\
$\mathrm{NaNO}_{3} * \mathrm{NaCl}(\mathrm{L})$ & -1.10 & 0.147 & -2.97 & 0.030 & -2.63 & 0.470 & -8.82 & 0.363 \\
\hline
\end{tabular}

The concentration of $\mathrm{NaNO}_{3}$ in the culture medium had a significant $(\mathrm{p}<0.05)$ and negative $(-$ 3.39) effect on the protein concentration in the biomass, indicating that increasing the concentration of this nutrient in the culture medium decreases the concentration of proteins in the microalgal biomass. Thus, the maximum concentration of proteins in biomass $(62.4 \%)$ was found in assay 1 , which had a lower nitrogen concentration $\left(1.25 \mathrm{~g} \mathrm{~L}^{-1}\right.$ of $\left.\mathrm{NaNO}_{3}\right)$. However, the most pronounced reduction of protein $(4.5 \%)$ occurred when it increased the concentration of nitrogen ( 1.25 to $2.50 \mathrm{~g} \mathrm{~L}^{-1}$ ) and maintained the sodium chloride concentration at $30 \mathrm{~g} \mathrm{~L}^{-1}$. In this context, it is believed that the use of $\mathrm{NaCl}$ at thirty times the normal level may have had a synergistic effect with increasing the nitrogen source.

Nitrogen is an essential element and is indispensable for the growth of microalgae because the formation of amino acids, proteins, enzymes, coenzymes and chloroplasts, and so forth is associated with the uptake of this compound (Turpin, 1991). Therefore, the results that were obtained in this study can be explained by the fact that the same concentration of $\mathrm{NaNO}_{3}$ was used for the inoculum adaptation. Another explanation for the higher content of proteins being found with the lowest concentration of $\mathrm{NaNO}_{3}$ is that, according to Colla et al. (2007), at 30 ${ }^{\circ} \mathrm{C}$, the absorption of the culture medium's nitrogen by the microalgae is limited.

In all of the assays that were carried out, regardless of the concentrations of $\mathrm{NaCl}$ and $\mathrm{NaNO}_{3}$ that were used in the cultivation, the concentrations of proteins in the Spirulina sp. LEB 18 biomass were superior to the results found by Ravelonandro et al. (2011). These authors found that the protein concentration in the biomass of Spirulina platensis decreased from $50.0 \pm 2.0 \%$ to $38.0 \pm 1.0 \%$ when the $\mathrm{NaCl}$ concentration increased from 13.0 to $35.0 \mathrm{~g} \mathrm{~L}^{-1}$.

The protein concentration is an important factor when assessing the nutritional value of microalgae. Spirulina cultivation can be an alternative to produce proteins for human or animal 
consumption (Spolaore et al. 2006). In Zarrouk culture medium, on bench and pilot scales, the protein concentration in Spirulina can reach values between 62.0\% ( $\left.\mathrm{w} \mathrm{w}^{-1}\right)$ (Borges et al. 2013) and $86.0 \%\left(\mathrm{w} \mathrm{w}^{-1}\right)$ (Morais et al. 2009), respectively.

The $\mathrm{NaCl}$ concentration and the interaction between the variables $\left(\mathrm{NaNO}_{3} \mathrm{X} \mathrm{NaCl}\right)$ had a significant effect $(\mathrm{p}<0.05)$ on the concentration of carbohydrates in the biomass of Spirulina sp. LEB 18. The concentration of $\mathrm{NaCl}$ had a positive effect (2.44), which shows that increasing the concentration of this compound in the culture medium may increase the amount of carbohydrates of the microalgal biomass. However, the interaction had a negative and, in modulus, higher effect $(-2.97)$ regarding the concentrations of carbohydrates in the biomass. Therefore, this effect demonstrates that an increase in the amount of $\mathrm{NaCl}$ and $\mathrm{NaNO}_{3}$ in the culture medium may reduce the concentration of carbohydrates of the biomass.

The experimental design contemplated the optimal point (central points) for carbohydrates concentration of the Spirulina biomass compared to the tested concentrations of $\mathrm{NaNO}_{3}$ and $\mathrm{NaCl}$. This was in such a way that the estimate of curvature was statistically significant (Table 4 ), and the realization of axial points (-1.41 and 1.41) of the experimental design would probably lead to the optimization of the concentration of the microalgal carbohydrate.

A low nitrate, phosphate and bicarbonate concentration combined with an increased concentration of sodium chloride in the culture medium results in a substantial increase in the carbohydrate fraction of the microalgal cells and reduces the total protein content (Tadros, 1991). Vonshak et al. (1988) and Martel et al. (1992) reported that Spirulina platensis that was subjected to saline stress increased the metabolism of carbohydrate production in cells. According to Vonshak (1997), in the presence of $0.5 \mathrm{~mol} \mathrm{~L}^{-1}\left(29.3 \mathrm{~g} \mathrm{~L}^{-1}\right) \mathrm{NaCl}$ in the cultivation, the maximum accumulation of carbohydrates in the Spirulina biomass was $64.4 \%$ $\left(\mathrm{w} \mathrm{w}^{-1}\right)$.

When the microalga Scenedesmus obliquus was deprived of nitrogen, there was a $26.0 \%$ reduction in protein concentration, whereas the concentrations of lipids and carbohydrates increased by approximately $11.0 \%$ and $14.0 \%$, respectively. In this study, the carbohydrate concentrations increased with the time of deprivation and peaked at $51.8 \%$ after $7 \mathrm{~d}$ of cultivation (Ho et al. 2012).

The concentration of lipids in the biomass of Spirulina sp. LEB 18 did not present reproducibility in the central points (Table 3). The concentration of lipids was not significantly $(\mathrm{p}>0.05)$ influenced by the levels of $\mathrm{NaNO}_{3}$ and $\mathrm{NaCl}$ in the culture medium or by the interaction between these variables (Table 4). However, the lipid concentrations that were observed in this study were higher than the $5.0 \%$ that was reported by Borges et al. (2013) when using Spirulina sp. LEB 18 and to the $4.0 \%$ found by Batista et al. (2013) when using the biomass of Spirulina maxima.

\section{$\mathrm{CO}_{2}$ Biofixation by Spirulina}

The $\mathrm{CO}_{2}$ biofixation rate by Spirulina was not significantly influenced by the concentrations of $\mathrm{NaNO}_{3}$ and $\mathrm{NaCl}$ in the culture medium or by the interaction between the variables $(\mathrm{p}>0.05)$ (Table 4).

In addition to nitrogen limitation and higher salinity, adding $\mathrm{CO}_{2}$ to the cultivation can increase biocompounds, such as carbohydrates and lipids, due to the greater incorporation of carbon by the microalga (Hsueh et al. 2009).

Microalgae contain approximately $50.0 \%\left(\mathrm{w} \mathrm{w}^{-1}\right)$ carbon in their composition (Amaro et al. 2011). The elemental concentration of carbon for the assays was maintained in the range of 46.0 to $49.5 \%$, with the maximum $\left(49.5 \%\right.$ ) found in assay 3 (Table 3), with $1.25 \mathrm{~g} \mathrm{~L}^{-1} \mathrm{NaNO}_{3}$ and $30 \mathrm{~g} \mathrm{~L}^{-1} \mathrm{NaCl}$.

The maximum $\mathrm{CO}_{2}$ biofixation rate was $197.4 \mathrm{mg} \mathrm{L}^{-1} \mathrm{~d}^{-1}$ (assay 1), 38.7\% higher than the lowest $\mathrm{R}_{\mathrm{CO} 2}$ that was obtained in assay $6\left(142.0 \mathrm{mg} \mathrm{L}^{-1} \mathrm{~d}^{-1}\right)$. In assays 3 and 4 , the reductions of $\mathrm{R}_{\mathrm{CO} 2}$ were also checked against assay 1 . This behavior indicates that the concentrations of 15.0 and $30.0 \mathrm{~g} \mathrm{~L}^{-1} \mathrm{NaCl}$ may result in decreased biomass productivity and thus in the reduction of $\mathrm{CO}_{2}$ biofixation by the microalga.

The $\mathrm{CO}_{2}$ biofixation rates that were found in this study (Table 3) were higher than the maximum $\mathrm{R}_{\mathrm{CO} 2}$ that was obtained in assays with Spirulina sp. LEB $18\left(118 \mathrm{mg} \mathrm{L}^{-1} \mathrm{~d}^{-1}\right)$, Chlorella vulgaris LEB $106\left(124 \mathrm{mg} \mathrm{L}^{-1} \mathrm{~d}^{-1}\right)$ and Scenedesmus obliquus LEB $22\left(88 \mathrm{mg} \mathrm{L}^{-1} \mathrm{~d}^{-}\right.$ ${ }^{1}$ ) in Zarrouk medium and $12 \% \mathrm{v} / \mathrm{v}$ of $\mathrm{CO}_{2}\left(1.08 \mathrm{~d}^{-1}\right)$ by Radmann et al. (2011). This result shows that Spirulina can achieve high $\mathrm{CO}_{2}$ biofixation rates, even under conditions of saline 
stress and nitrogen limitation. Thus, the results that were obtained in this study reveal that the cultivation and production of Spirulina biomass can be carried out and that the applicability of biomass can be expanded, for example, in the production of carbohydrates.

\section{CONCLUSION}

The highest growing results $\left(\mathrm{X}_{\max }=1.60 \mathrm{~g} \mathrm{~L}^{-1}, \mathrm{P}_{\max }=0.109 \mathrm{~g} \mathrm{~L}^{-1} \mathrm{~d}^{-1}, \mu_{\max }=0.208 \mathrm{~d}^{-1}\right)$ and $\mathrm{CO}_{2}$ biofixation rate $\left(197.4 \mathrm{mg} \mathrm{L}^{-1} \mathrm{~d}^{-1}\right)$ were obtained when Spirulina sp. LEB 18 was cultivation with $1.25 \mathrm{~g} \mathrm{~L}^{-1} \mathrm{NaNO}_{3}$ and $1.0 \mathrm{~g} \mathrm{~L}^{-1} \mathrm{NaCl}$. Increasing the $\mathrm{NaCl}$ concentration in the culture medium can increase the concentration of carbohydrate in the biomass. The concentration of lipids was not significantly affected by the concentrations of $\mathrm{NaCl}$ and $\mathrm{NaNO}_{3}$. Regarding the protein concentration in the biomass, increasing the concentration of $\mathrm{NaNO}_{3}$ in the medium can reduce the concentration of this compound in the biomass. Thus, osmotic stress and the nitrogen deficiency increased the biosynthesis of carbohydrates and did not alter the protein concentration of the Spirulina. Besides, in these conditions, Spirulina was able biofix of $\mathrm{CO}_{2}$, reducing the emissions of this greenhouse gas.

\section{ACKNOWLEDGEMENTS}

The authors thank Eletrobras-CGTEE (Centrais Elétricas Brasileiras S.A.-Companhia de Geração Térmica de Energia Elétrica) and CAPES (Coordenação de Aperfeiçoamento de Pessoal de Nível Superior) for the financial support provided to conduct this work, and the Program of Support to Publication of the Academic Production/PROPESP/FURG/2015.

\section{REFERENCES}

1. Alava D, Mello PC, Wagener K. The relevance of the $\mathrm{CO}_{2}$ partial pressure of sodium bicarbonate solutions for the mass cultivation of the microalga Spirulina. J Brazil Chem Soc. 1997; 8: 447-450.

2. Amaro HM, Guedes A, Malcata FX. Advances and perspectives in using microalgae to produce biodiesel. Appl Energ. 2011; 88 (10): 3402-3410.

3. Batista AP, Gouveia L, Bandarra NM, Franco JM, Raymundo A. Comparison of microalgal biomass profiles as novel functional ingredient for food products. Algal Research. 2013; 2:164-173.

4. Borges JA, Rosa GM, Meza LHR, Henrard AA, Souza MRAZ, Costa JAV. Spirulina sp. LEB-18 culture using effluent from the anaerobic digestion. Braz J Chem Eng. 2013; 30 (2): 277-287.

5. Brand LE. The salinity tolerance of forty-six marine phytoplankton isolates. Estuar Coast Shelf S. 1984; 18 (5): 543-556.

6. Cohen Z. The Chemicals of Spirulina. In: Vonshak A. Spirulina platensis (Arthrospira) Physiology, cell-biology and biotechnology. London: Taylor \& Francis Ltd; 1997. p. 175204.

7. Colla LM, Reinehr CO, Reichert C, Costa JAV. Production of biomass and nutraceutical compounds by Spirulina platensis under different temperature and nitrogen regimes. Bioresource Technol. 2007; 98 (7): 1489-1493.

8. Costa JAV, Colla LM, Duarte Filho P, Kabke K, Weber A. Modeling of Spirulina platensis growth in fresh water using response surface methodology. World J Microb Biot. 2002; 18: 603-607.

9. Folch J, Lees M, Stanley GHS. A simple method for isolation and purification of total lipids from animal tissues. J Biol Chem. 1957; 226: 497-509.

10. Gabbay-Azaria R, Schofeld M, Tel-Or S, Messinger R, Tel-Or E. Respiratory activity in the marine cyanobacterium Spirulina subsalsa and its role in salt tolerance. Arch Microbiol. 1992; 157:183-190.

11. Glass ADM. Regulation of ion transport. Annu Rev Plant Phys. 1983; 34 (1): 311-326.

12. Hende SV, Vervaeren H, Boon N. Flue gas compounds and microalgae: (Bio-) chemical interactions leading to biotechnological opportunities. Biotechnol Adv. 2012; 30: 14051424. 
13. Ho S-H, Chen C-Y, Chang J-S. Effect of light intensity and nitrogen starvation on $\mathrm{CO}_{2}$ fixation and lipid/carbohydrate production of an indigenous microalga Scenedesmus obliquus CNW-N. Bioresource Technol. 2012; 113: 244-252.

14. Ho S-H, Chen C-Y, Lee D-J, Chang J-S. Perspectives on microalgal $\mathrm{CO}_{2}$-emission mitigation systems - A review. Biotechnol Adv. 2011; 29: 189-198.

15. Hsueh HT, Li WJ, Chen $\mathrm{HH}$, Chu H. Carbon bio-fixation by photosynthesis of Thermosynechococcus sp. CL-1 and Nannochloropsis oculta. J Photoch Photobio B. 2009; 95: 33-39.

16. $\mathrm{Hu} \mathrm{Q}$. Environmental effects on cell composition. In: Richmond A. Handbook of Microalgal Culture: Biotechnology and Applied Phycology. Ed. Blackwell Science Ltd, 2004. p. 83-93.

17. Hughes E, Benemann J. Biological fossil $\mathrm{CO}_{2}$ mitigation. Energy Convers Manage. 1997; 38: 467-473.

18. Jiang L, Luo S, Fan X, Yang Z, Guo R. Biomass and lipid production of marine microalgae using municipal wastewater and high concentration of $\mathrm{CO}_{2}$. Appl Energ. 2011; 88: 3336-3341.

19. Lee, JS, Kim, DK, Lee, JP, Park, SC, Koh, JH, Cho, HS, Kim, SW, 2002. Effects of $\mathrm{SO}_{2}$ and NO on growth of Chlorella sp. KR-1. Bioresource Technol. 2002; 82: 1-4.

20. Lourenço SO, Barbarino E, Lavín PL, Marquez UML, Aidar E. Distribution of intracellular nitrogen in marine microalgae: calculation of new nitrogen-to-protein conversion factors. Eur J Phycol. 2004; 39: 17-32.

21. Mackay MA, Norton RS, Borowitzka LJ. Organic osmoregulatory solutes in cyanobacteria. J Gen Microbiol. 1984; 130: 2177-2191.

22. Martel A, Yu S, Garcia-Reina G, Lindblad P, Pedersen M. Osmoic-adjustement in the cyanobacterium Spirulina platensis: presence of and $\alpha$-glucosidase. Plant Physiol bioch. 1992; 30 (5): 69-74.

23. Miller GL. Use of de dinitrosalicylic acid reagent for determination of reducing sugar. Anal Chem. 1959; 31 (3): 426-428.

24. Morais MG, Costa JAV. Carbon dioxide fixation by Chlorella kessleri, C. vulgaris, Scenedesmus obliquus and Spirulina sp. cultivated in flasks and vertical tubular photobioreactors. Biotechnol Lett. 2007; 29: 1349-1352.

25. Morais MG, Radmann EM, Andrade MR, Teixeira GG, Brusch LRF, Costa JAV. Pilot scale semicontinuous production of Spirulina biomass in southern Brazil. Aquaculture. 2009; 294 (1-2): 60-64.

26. Morais MG, Reichert CC, Dalcanton F, Durante AJ, Marins LF, Costa JAV. Isolation and Characterization of a New Arthrospira Strain. Z Naturforsch. 2008; 63: 144-150.

27. Mutlu YB, Isik O, Uslu L, Koç K, Durmaz Y. The effects of nitrogen and phosphorus deficiencies and nitrite addition on the lipid content of Chlorella vulgaris (Chlorophyceae). Afr J Biotechnol. 2011; 10 (3): 453-456.

28. Peschek GA, Obinger C, Fromwald S, Bergman B. Correlation between immuno-gold lables and activities of cytochrome-c oxidase(aa-type) in membranes of salt stressed cyanobacteria. FEMS Microbiol Lett. 1994; 124: 431-437.

29. Radmann EM, Camerini FV, Santos TD, Costa JAV. Isolation and application of $\mathrm{SO}_{\mathrm{X}}$ and $\mathrm{NO}_{\mathrm{X}}$ resistant microalgae in Biofixation of $\mathrm{CO}_{2}$ from thermoelectricity plants. Energ Convers Manage. 2011; 52: 3132-3136.

30. Rao AR, Dayananda C, Sarada R, Shamala TR, Ravishankar GA. Effect of salinity on growth of green alga Botryococcus braunii and its constituents. Bioresource Technol. 2007; 98: 560-564.

31. Ravelonandro PH, Ratianarivo DH, Joannis-Cassand C. Improvement of the growth of Arthrospira (Spirulina) platensis from Toliara (Madagascar): Effect of agitation, salinity and $\mathrm{CO}_{2}$ addition. Food Bioprod Process. 2011; 89: 209-216.

32. Reed RH, Borowitzka LJ, Mackay MA, Chudek JA, Foster R, Warr SRC, et al. Organic solute accumulation in osmotically stressed cyanobacteria. FEMS Microbiol Rev. 1986; 39: $51-56$.

33. Siaut M, Cuine S, Cagnon C, Fessler B, Nguyen M, Carrier P, et al. Oil accumulation in the model green alga Chlamydomonas reinhardtii: characterization, variability between common laboratory strains and relationship with starch reserves. BMC Biotechnol. 2011; $11(7): 2-15$. 
34. Spolaore P, Joannis-Cassan C, Duran E, Isambert A. Commercial applications of microalgae. J Biosci Bioeng. 2006; 101: 87-96.

35. Sudhir P-R, Pogoryelov D, Kovács L, Garab G, Murthy SDS. The Effects of Salt Stress on Photosynthetic Electron transport and Thylakoid Membrane Proteins in the Cyanobacterium Spirulina platensis. J Biochem Mol Biol. 2005; 38 (4): 481-485.

36. Subhadra B, Edwards M. An integrated renewable energy park approach for algal biofuel production in United States. Energ Policy. 2010; 38 (9): 4897-4902.

37. Tadros, M. Chemical composition of cyanobacteria: Spirulina maxima in response to nutrients, in bath cultures. In: Second International Marine Biotechnology Conference (IMBC/91), 1991, Baltimore, USA. p.13-16.

38. Teófilo RF, Ferreira MMC. Quimiometria II: planilhas eletrônicas para cálculos de planejamentos experimentais, um tutorial. Quim Nova. 2006; 29 (2): 338-350.

39. Toledo-Cervantes A, Morales M, Novelo E, Revah S. Carbon dioxide fixation and lipid storage by Scenedesmus obtusiusculus. Bioresource Technol. 2013; 130: 652-658.

40. Turpin, DH. Effects of inorganic $\mathrm{N}$ availability on algal photosynthesis and carbon metabolism. J Phycol.1991; 27: 14-20.

41. Vonshak A, Guy R, Guy M. The response of the filamentous cyanobacterium Spirulina platensis to salt stress. Arch Microbiol. 1988; 150: 417-420.

42. Vonshak A. Outdoor mass production of Spirulina. In: Vonshak A. Spirulina platensis (Arthrospira) Physiology, cell-biology and biotechnology. London: Taylor \& Francis Ltd, 1997. p. 79-99.

43. Zarrouk, C. Contribution à l'étude d'unecyanophycée. Influence de diversfacteurs physiques et chimiquessur la croissance et photosynthese de Spirulina maxima Geitler. Ph.D. Thesis, University of Paris, 1966. 